\title{
The Storytelling Method With Role Playing Techniques to Grow Noble Character
}

\author{
Ari Kartiko \\ KH Abdul Chalim PacetMojokerto \\ Ari.kartiko5@gmail.com \\ Edy Kurniwan \\ Pesantren InstituteKH Pesantren Institute KH. Abdul Chalim Pacet Mojokerto \\ edykurniawan2497@gmail.com
}

\begin{abstract}
Education plays an important role in achieving the ideals of the Indonesian people in accordance with the formulation of the 1945 Constitution which clearly states that the purpose of education is to promote public welfare and educate the life of the nation, essentially the realization of these noble individuals of course it will balance the nation's intelligence in prospering the country. Based on this, education must be able to foster noble character so that later can produce generations that are intelligent and useful for the nation. The problem lies in how to cultivate noble character in students. School institutions by means of teacher teaching are central to instilling students' noble character. Therefore this study aims to find out how storytelling and role playing activities can foster noble character. This study uses qualitative research with the type of research library. Research libraries are research techniques using book sources to develop science. Clear information and sources have been arranged systematically. Storytelling with role playing techniques is something that students really like. This will be learning that can stimulate student activity. Inserting values into a story will be useful in developing noble character. Noble character is a sincere and conscious act that arises from within a person. By telling stories, students will get knowledge about good grades and role playing will provide opportunities for students to apply the knowledge gained. So that it will become good habits and emerge noble character in students.
\end{abstract}

Keywords: storytelling, role playing, noble character

\section{Introduction}

A. Background

Education in schools has become an obligation of all Indonesians. Compulsory 9 years of education has been regulated in Law No. 20 of 2003 Article 3 concerning the National Education System which functions to realize a democratic and responsible state with the balance of character or noble character and scientific intelligence of students.

In the present era there are many problems faced by our country due to lack of morals from the next generation, such as corruption and abuse of authority on duty. The output of an educational institution is very alarming because it is not in line with educational goals. There have been many Indonesian people who have been victims of intelligent but unqualified officials. This is due to the lack of emphasis on the educational process in the learning process.

We recommend that the problems that hit our country can be overcome with education. If education can carry out its role properly, the goal of education can be achieved in real terms. So that the output of the nation's next generation is able to build this country. Embedded morals 
in the Indonesian community will minimize problems such as corruption, skipping work and so on.

In the world of education there are many determinants of student success such as the method used by teachers in teaching. The method is the way teachers convey knowledge to students. The application of learning methods should be adjusted to the characteristics of all students in the classroom. So that the teaching and learning process runs effectively and efficiently.

Madrasah Ibtidaiyah (MI) School is the first formal institution to become a place for student learning. The average age of students in MI is between 7-12 years. This age is the golden age of students so it is suitable for instilling a foundation of values and knowledge. However, in the learning process, caution is needed because MI students tend to imitate what they have seen.

Characteristics of students in general in Madrasah schools are like playing and hearing stories. MI students who feel happy in the learning process are easier to capture knowledge. An MI teacher should be able to set the learning step with the elements of the story and play in it so that the learning objectives can be achieved effectively and efficiently.

Storytelling in the learning process should contain moral values so students get value knowledge. With this knowledge students will appreciate doing a good deed. A teacher must be able to know the student's desire to act so that in the learning process can use it to maximize the achievement of goals.

Role playing techniques in storytelling are suitable techniques for implementing student actions. Role playing is commonly known as students playing roles. In a strategy with this technique students are given the opportunity to appreciate the value and knowledge they have received. So that it can stimulate active students in learning.

By using the strategy of storytelling with role playing techniques, it will effect the learning objectives and values to form noble character. Noble character is a conscious act of someone to do a good deed. Students who are noble will be the perfect generation to build the nation.

\section{Discussion of}

A. Storytelling

${ }^{1}$ According to Ismoerdijahwati (2007) that storytelling is the art of delivering the value of an event through words that are designed in such a way with the ability to imagine a storyteller. Conveying an important thing with a story that has been neatly arranged to someone is also told.

${ }^{2}$ Storytelling is the delivery or presenting of stories verbally to someone. In storytelling learning is a method or step taken to convey the subject matter. The method is a systematic step in conveying certain developments. The method of storytelling is the delivery of lessons through stories verbally by adding learning experiences in the form of moral values.

\footnotetext{
${ }^{1}$ Musdalifah M. Rahman, "methodof Forming Tells Muslim Personality In Childhood Dini "Vol. 1 No. 1, JulyDecember 2013, p. 76.

${ }^{2}$ Try Setiantono," TheUse of Storytelling Methods for Early Childhood in Paud Smart Little Cilame

Indahbandung. "Empowerment. Vol. 1, No. 2, September 2012, hal 22.
} 
${ }^{3}$ Interesting things in the story that can produce various kinds of feelings, an imagination that touches the heart so that it creates a strong feeling that can move someone to do something. That is why the story becomes a popular source / material for teachers in shaping and developing students' noble character.

In general, MI students like the story and even become a favorite of students., Tim Kent as a moral teacher at Dry Creek Elementary School, California. From the experience of Tim Kent who idolized this method was able to streamline learning because the students' enthusiasm in hearing stories was very high. The theme of the story that is often used by Tim Kent is the story of what students are interested in, such as the story of Cinderella, Toys Story, Reader Digets in others. Kent's team thought that storytelling was one of the most important teaching instruments and could distract students.

${ }^{4}$ The story of one form of story that is often used in learning. Tales contain a culture that contains various knowledge and moral values. The form of fairy tales is very suitable to be used in learning in MI because it can add experience and insight into moral values as a basis for a higher level. According to Tampubolon that "the contents of the story should be adjusted to the level of education and experience of students". This opinion aims to make the story understandable and interpreted by students. When students understand the story well, so does the arrest of the values contained in the story.

1. Benefits and Purpose of telling stories.

Benefits of storytelling methods for students:

a.) Becoming a trigger for students' brain in thinking critically to be able to understand the contents of a story.

b.) Helps to improve students' concentration in focusing their attention on the whole story.

c.) Develop students 'imagination that is able to improve the ability of students' right brain to be more productive so that it is easy to process information.

d.) Storytelling can increase students' learning experience in listening and listening to stories.

e.) Submission of good stories by teachers can increase students' language vocabulary so as to facilitate communication skills.

f.) Develop students' social spirit. Stories compiled by involving several characters in it reflect social life and togetherness.

g.) Develop students' noble character by instilling moral values into the story.

h.) Develop students' empathy. Empathy is the ability to know and feel the circumstances experienced by others.

i.) Develop student emotional intelligence. Emotional intelligence is a combination of students' social-emotional abilities. Students who have emotional intelligence students will be able to control themselves or their emotions so they can express their feelings well.

\footnotetext{
${ }^{3}$ Thomas Lickona, "Educating for Craracter Mendidik Untuk Membentuk Karakter", Jakarta; PT Bumi Aksara, 2012.

${ }^{4}$ Musdalifah M. Rahman, “Metode Bercerita Membentuk Kepribadian Muslim Pada Anak Usia Dini”. Vol. 1 No. 1, Juli-Desember 2013, hal. 76.
} 
${ }^{5}$ In the opinion of Dhieni stated that, the aim of the method of telling stories to students is that (a) students can listen carefully and pay attention to the teacher, (b) students can ask questions about the stories told by the teacher, (c) students can retell and express the stories they have heard. Of course there are more goals in telling stories such that students are able to listen to the content and moral values contained in the story.

From the above explanation about the purpose and benefits of storytelling, to make learning effective by paying attention to the three aspects of students' abilities namely cognitive, affective and spikomotor abilities of students.

2. Storytelling Steps.

${ }^{6}$ According to Dhieni the implementation of the storytelling method is arranged into five steps, including:

1) Managing student seats, when students feel relaxed and comfortable, students will feel at home when listening to stories. Storytelling activities do not have to be done in the classroom. Story activities can be done anywhere, provided they meet the criteria for cleanliness, safety and comfort.

2) Give students the opportunity to submit the title of the story, before students know the actual title of the story.

3) Determine the theme or title of the story.

${ }^{7}$ The thing that needs to be considered in the selection of stories is that the

a) story should attract and attract the attention of the students and the teacher itself.

b) The story is adapted to the style of personality and levels of education of students

c) Life-based stories in the student environment so that it is easy to digest the contents of the story.

4) Tell stories.

In addition to the use of media, in telling the story a teacher must have storytelling skills, namely, how to express movement and voice and the teacher's face according to the characters in the story and how to calm students.

5) Give students the opportunity to ask questions and draw conclusions. This step is to find out where students' attention to the story that has been delivered as a form of assessment in learning.

\footnotetext{
${ }^{5}$ Pebri Damaryanti1, Made Tegeh, Rahayu Ujianti, “Efektivitas Metode Bercerita Dengan Media Boneka Wayang Terhadap Kemampuan Bercakap-Cakap Anak Kelompok B Di Tk Widya Sesana". Vol. 5 No. 1, Tahun 2017, hal. 6.

${ }^{6}$ Ida Ayu Komang Sri Widianti, Ni Ketut Suarni, Nice Maylani Asril, "Penerapan Metode Bercerita Dengan Media Gambar Untuk Meningkatkan Keterampilan Berbicara Pada Anak". Vol. 3 No. 1, Tahun 2015, hal. 4.

${ }^{7}$ Musrid, "Pengembangan Pembelajaran PAUD" ROSDA, P. 33
} 
From the explanation above it can be seen that there are four important elements that need to be mastered by the teacher, namely classroom management, theme selection or story title, storytelling skills, and results assessment learning.

${ }^{8}$ The advantages of the story method

a. can be applied to classes that have many students.

b. Good management will make learning effective.

c. Easy in class mastery.

d. Do not use too much fees.

Lack of method of storytelling without the use of techniques

a. It is teacher center so students become passive

b. Less developing students' creativity because they only focus on listening to the story without any follow-up to the practice.

c. The success of learning is largely determined by the ability of a teacher to tell stories.

B. Role Playing

${ }^{9}$ According to Wilson that role playing is often applied in everyday life, that is from the ability of a person to express his experience in the form of a model. Role playing is a simple drama that aims to be a place for students to express their views. It means that role playing technique is a way to become a place for students to act as models in the classroom. In role playing has been set how to become a model and play a predetermined character.

${ }^{10}$ According to Adam Blatner, MD, suggests that Role Playing is also called sociodrama which is a method of repeating something that is considered important in relation to the relationship of social problems. The goal is to find out what is wrong and what lessons can be learned from the repetition.

Syaiful Bahri Djamarah and Aswan Zain stated the purpose of using role playing is:

1) Students can learn to respect the feelings of others with mutual tolerance.

2) Raising a sense of student responsibility for the roles that have been given in the group.

3) Instill good cooperation as democratic individuals.

\footnotetext{
${ }^{8}$ Ni Kadek Ayu Mekarningsih, I Nyoman Wirya, Mutiara Magta, "Penerapan Metode Bercerita Berbantuan Media Audio Visual Untuk Meningkatkan Kemampuan Berbahasa Lisan Pada Anak ". Vol. 3 No. 1, Tahun 2015, hal. 4.

${ }^{9}$ Imam Baihaqi, "Peningkatan Keterampilan Bermain Drama Dengan Metode Role Playing Pada Kelompok Teater Kenes Smpn 4 Yogyakarta". Vol. 12 No. 2, September 2016, hal. 7.

${ }^{10}$ Kiromim Baroroh, "Upaya Meningkatkan Nilai-Nilai Karakter Peserta Didik Melalui Penerapan Metode Role Paying". Vol. 8, No. 2, November 2011, hal. 150-151.
} 
4) Stimulate students as a whole to think critically in solving problems.

From Sutoso's opinion that the use of role playing methods has several advantages, namely as follows.

1) The game is played alone, helps in understanding the problems that are being faced.

2) Students can place themselves as well as characters from characters played.

3) Able to feel the feelings experienced by others. This is able to foster mutual respect and tolerance towards others.

C. Steps to Role Playing Techniques

According to Hamzah B Uno ${ }^{11}$ that the implementation of role playing is arranged into four stages, namely the preparation, implementation, assessment and closing stages. The four stages are explained as follows:

1. PreparationStage

Preparationis the first step that has a very important role to make effective the implementation of role playing. Steps in preparing the preparation as follows.

a. Determine the background of the problem initially found in the story to be carried out by students.

In determining / determining the background of the problem, a teacher should first understand the characteristics of all students in order to know well what problems are suitable and of interest to students.

b. The teacher prepares and prepares story scenarios and the role of students in performing role playing.

Scenario preparation is better done together with students so that students can be active in contributing ideas and ideas. The involvement of students will facilitate the following activities.

c. Set the role to be modeled by students.

Setting roles for each student is a little complicated because the teacher must understand each student's character so that there is conformity with the role of the character he gets. Therefore this determination must be held jointly with students so that the teacher gets additional ideas from students because students as classmates must understand better.

d. Students are formed into several groups of parts

This group division aims to adjust and facilitate students in practicing roles. This group division can form a sense of mutual help and respect for students.

\footnotetext{
${ }^{11}$ Kiromim Baroroh, “Upaya Meningkatkan Nilai-Nilai Karakter Peserta Didik Melalui Penerapan Metode Role Paying"....hal.151-152
} 
2. The Implementation Stage The

a. teacher conveys the competency standards and learning objectives expected after implementing role playing.

Submission of SK and learning objectives at the beginning of the implementation is useful to direct students about what will be achieved after doing role playing activities.

b. Students who have been divided into groups are organized according to their respective groups.

Unification of students based on their group aims to prepare students mentally by looking at and observing the scenario that they will do.

c. Implement role playing techniques masterminded by a teacher in accordance with the story.

This means that a teacher in the implementation of role playing not only silently observes and assesses students but also takes the role of a puppeteer. The puppeteer is the person in charge of reading the storyline so that the story runs effectively and efficiently.

3. Assessment Phase

a. Giving student worksheets to deduce results from role playing activities.

This activity aims to measure how well students understand the lessons that have been done before by using the role paying method.

b. Give the opportunity for several students to convey the results of the conclusions that have been written.

This activity aims to strengthen student knowledge and as a step to develop the value of responsibility with what he has written.

c. The teacher conveys the actual conclusions in general.

Submission of conclusions by the teacher aims to tell students clearly how to conclude well and understand students so that students' knowledge is not wrong and diverse.

4. Closing

a. Evaluation.

Evaluation activities aim to find out the effectiveness and efficiency of learning systems that have been used previously. The defensive system in question is in the form of role playing methods that are used, goals, learning resources, etc. These evaluations are carried out so that further activities can run better.

b. Closing.

D. Noble Morals

Understanding morality according to Imam Abu Hamid al-Ghazali that morality is the nature and behavior that comes from the bottom of most hearts in humans without being 
influenced by reason first. If the character that is raised by someone is good then it is called good character or noble character while if the character that appears bad then it is called bad character. ${ }^{12}$

According to Halim, morality has four meanings, namely moral which means a set of rules agreed upon by someone to form actions that are considered good based on terms, philosophy, with the aim of creating a humanism life.

So, noble character is everything that a person's soul brings to do a good deed in a conscious situation. Noble character is a praiseworthy trait that can prevent despicable traits from occurring in human life.

Humans who have noble character are pride in themselves and the surrounding community. With noble character in human beings can have an impact on the establishment of positive interactions so that peace and social comfort occur. Comfort in the school environment is hope for all members of the educational institution. Of course with this it will facilitate the achievement of goals because of the harmony of all members of the school institution.

The output of school institutions with noble character will later develop the country and eliminate cases of state obstacles to prosperity. The next generation who will instill moral values as the basis of education which is also the core education goal in Indonesia.

E. Strategy Analysis Storytelling With Role Playing Techniques to Grow Noble Morals

In storytelling strategy learning has been proven to be able to develop the noble character of students. The insertion of values into the story will be a plus for this strategy. In addition, the storytelling strategy is also very favored by students in learning because stories are considered pleasant. But the simple method of classic storytelling by using story books is still considered unsuitable because it has many disadvantages.

In accordance with scientific developments within the scope of the learning method, new techniques have been developed that can cover the shortcomings of the story method. One of the techniques is role playing techniques, the use of story books and the use of puppets in storytelling.

Popular storytelling techniques are used, namely the use of story books, puppets. This method is indeed suitable for MI / elementary school students because the use of teaching aids in the form of dolls can relax abstract characters. But in my opinion this technique is effective in learning because students only see and listen to stories. So that is achieved only in the cognitive and affective goals. While the goal of student spicomorphic is not achieved. If those three aspects are not achieved then it is difficult to form the noble character of the students.

The general storytelling method still has some disadvantages such as storytelling without the use of techniques so students are only able to develop their listening and viewing skills and this is not enough to foster students' noble character. Therefore, developers using

\footnotetext{
${ }^{12}$ Sabar Budi Raharjo, " Pendidikan Karakter Sebagai Upaya Menciptakan Akhlak Mulia", Vol. 16, Nomor 3, Mei 2010, hal 233
} 
role playing techniques in storytelling methods will minimize and even eliminate these deficiencies. Role playing techniques become a place for students to chant the stories they hear so that students who are initially passive become active. Students are also more creative in expressing their opinions.

The use of role playing techniques that have a cooperative model can improve students' social competence. ${ }^{13}$ Social competence is the ability of students in (a) understanding the feelings of others (b) improving communication skills (c) increasing cooperation in role playing and (d) increasing responsibility for roles and rules.

Therefore, the effectiveness of this storytelling method with role playing techniques is undoubtedly in improving students' noble character because in every story there is a moral message containing the values of empathy. Values inserted into the story become moral knowledge for students. Then from moral knowledge comes the desire to do good and finally apply the morality in an action.

${ }^{14}$ Planting moral values into the souls of students is also influenced by the function of the teacher as a facilitator and communicator. This means that in the learning process the task of a teacher is not only as a teacher but also facilitates and communicates warmly with students. If a teacher can carry out the task well then students can receive lessons and moral values effectively and efficiently.

Morality in the view of Islam is the basic point on which to calculate and evaluate the good and bad things. The foundation is not based on human views but on the commands and prohibitions of Allah SWT, therefore good character arises from obedience and obedience only to Allah SWT. The consideration is based on one verse in QS. An-Nisa and Surah Al Ahzab which means:

"O ye who believe, obey Allah and obey His Messenger and Ulil Amri among you, then if you disagree about something then return it to Allah (Al-Qur'an) and the Messenger (sunnab) if you truly believe in Allah and the final day, such is more important (for you) and better results. "(An-Nisa: 59)

"Verily there is in the Messenger of Allah is an example that is good for you (ie) for those who expect (grace) Allah and (arrival) the Day of Judgment and he calls Allah a lot. "(Surat alAhrab: 21)

From these two verses it can be concluded that good morals have been imitated in the Prophet, both from words and deeds.

One of the sciences that refers to and has in common with noble behavior is mysticism. In mysticism someone tries to purify himself by doing good in order to reach zuhud. Zuhud is abandoning morality which is considered bad by Allah SWT. Everything that is considered good by God will be considered good by fellow humans. Moral science with Sufism is related to one another. In this case it appears in the same values in terms of piety to the creator.

\footnotetext{
13 Dwi Bhakti Indri M.," Religious Spirituality - cognitive Behaviour Therapy Untuk Meningkatkan Selfconfidence Dalam Social Interaction Anak Usia Dini" Nidhomul Haq, Vol. 1, No. 2, November 2016. ${ }^{14}$ Muhammad Anas Ma'arif, "Pendidikan Islam Dan Tantangan Modernitas (Input, Proses, dan Output di Madrasah)" Nidhomul Haq, Vol. 1, No. 2, Juli 2016.
} 
As faithful people we must follow the example of the Prophet. To find out what is done by him, many books present it. But MI students will certainly get bored if they have to read the book in learning. Therefore, the technique of storytelling with role playing in learning is very good to form noble character.

Telling stories about the prophets can bring students appreciation in doing good. Appreciation of students must be accommodated in a learning concept so that it can be applied directly in learning and even have an effect on the future when outside the classroom. The role playing technique is a container that can apply the actions of students.

In the world of noble moral education is one of the goals of national education. Many think that if the noble character of the students has been eaten, the purpose of education has also been achieved. The nature of education is preparation by assisting students to develop their soul and knowledge.

Social science or referred to as sociology also relates to the formation of noble character morals. Sociology that emphasizes human life in society, both from the way of interacting with other people. The basis of this sociological science lies in how humans can survive in a community group. Therefore a human being must have good character so that it is easily accepted by the surrounding community. In moral science gives a concept and description to someone about the ideal form of society regarding one's behavior in society.

The scientific development of learning methods tells the story in line with the research conducted by Mega Yulianti under the title "The Role of the Storytelling Method in Developing Moral Values in Children in B2 Group Pertiwi Palu". In this study proves the magnitude of the role of the story telling model in developing moral values such as aspects of respecting friends, improving manners, and developing students' responsibilities.

Although in previous studies about the influence of methods tell the development of moral values of students, but I assume that there are similarities between moral values and noble character. In accordance with the opinion of Wantah in Webster's new World dictionary which states that morality is something that is related or related to the ability to determine right or wrong and good and bad behavior. Then continued with Chaplin's argument in the dictionary of psychology that morality refers to morals that are in conformity with social regulations, or that there is an attachment to the law or customs that becomes a habit of behaving. ${ }^{15}$ From that opinion, I conclude that morals and morals are things that have in common, such as being equally related to both bad behavior, right wrong behavior, beliefs and also the impact on the social environment of society. Therefore, I try to develop knowledge from previous researchers 'suggestions to maximize the method of telling stories by using storytelling techniques that can increase students' enthusiasm and activity. The technique I use is the role playing method.

Role playing techniques are also proven to improve students' noble character. In the previous study by Kiromim Baroroh about the application of role paying to improve the character of students. The results of this study indicate that role playing can improve the

${ }^{15}$ Dian Ibung,(2008)"Pengembangan Nilai Moral Pada Anak".Jakarta:PT Elex Media Komputido 
character of discipline, hard work, creative, and communicative students that are part of the reflection of the noble character of students.

Viewed from the point of view of the nature and attitude of behavior produced by noble characters, morals and character, it is indistinguishable because both manifest human beings who behave well and benefit themselves and the surrounding community.

${ }^{16}$ Noble character is a spiritual intelligence of students that must be improved because with spiritual values can be a solid foundation for developing various other skills. Noble character itself can be seen from the level of devotion to Allah SWT. Taqwa is the implementation of all of Allah's commands with feelings of pleasure and love because of His blessing which is also the responsibility of humanity.

\section{Conclusion}

Noble character plays an important role in realizing educational goals. Morality is a good deed that appears to yourself. Without good character, the knowledge gained will be in vain because it does not live in society.

Education in Indonesia has led to the formation of noble character in students so as to produce generations that are able to improve the quality of human resources. In educational institutions, especially in the learning process requires the right strategy, namely the strategy of telling stories with role playing techniques to develop students' noble character.

The strategy of telling stories with role playing techniques is a way of learning by using stories and playing roles to instill and develop knowledge and noble character.

With the achievement of noble character, students can develop other sciences. It is proven by good behavior in treating books and teachers as a source of student learning. Students with noble character will be very useful outputs for the community to achieve prosperity and peace.

\footnotetext{
${ }^{16}$ Dwi Bhakti Indri M. "Spiritual Quotient Sebagai Pilar Karakter" Dosen IKHAC : Jurnal, hal 5-6
} 


\section{REFERENCES}

Baihaqi, I. (2016). Peningkatan Keterampilan Bermain Drama dengan Metode Role Playing pada Kelompok Teater Kenes SMPN 4 Yogyakarta. Transformatika: Jurnal Bahasa, Sastra, Dan Pengajarannya, 12(2), 15-28.

Baroroh, K. (2011). Upaya meningkatkan nilai-nilai karakter peserta didik melalui penerapan metode role playing. Jurnal Ekonomi \& Pendidikan, 8(2).

Dian Ibung. (2009). Mengembangkan Nilai Moral Pada Anak. Jakarta: Elex Media Komputindo.

Hamzah B, U. (2011). Profesi Kependidikan, Problema, Solusi dan Reformasi di Indonesia. Jakarta: Bumi Aksara.

Lickona, T. (2009). Educating for character: how our schools can teach respect and responsibility. New York: Bantam Books.

M, D. B. I. (2016). Religious Spirituality - Cognitive Behaviour Therapy Untuk Meningkatkan Self-Confidence Dalam Social Interaction Anak Usia Dini. Nidhomul Haq: Jurnal Manajemen Pendidikan Islam, 1(3), 162-178. https://doi.org/10.31538/ndh.v1i3.15

Ma`arif, M. A. (2016). Pendidikan Islam dan Tantangan Modernitas. Nidhomul Haq: Jurnal Manajemen Pendidikan Islam, 1(2), 47-58.

Ma`arif, M. A. (2018). Analisis Strategi Pendidikan Karakter Melalui Hukuman Preventif. Ta'allum: Jurnal Pendidikan Islam, 6(1), 31-56. https://doi.org/10.21274/taalum.2018.6.1.31-56

Ma'arif, M. A. (2017). Hukuman (punishment) Dalam Perspektif Pendidikan Di Pesantren. Ta'allum: Jurnal Pendidikan Islam, 5(1), 1-20. https://doi.org/10.21274/taalum.2017.5.1.120

Mekarningsih, N. K. A., Wirya, N., \& Magta, M. (2015). Penerapan Metode Bercerita Berbantuan Media Audio Visual Untuk Meningkatkan Kemampuan Berbahasa Lisan Pada Anak. Jurnal Pendidikan Anak Usia Dini Undiksha, 3(1).

Mursid. (2015). Pengembangan Pembelajaran PAUD. Bandung: Remaja Rosdakarya.

Putu, P. D. N., Tegeh, I. M., Ujianti, P. R., \& Psi, S. (2017). Efektivitas Metode Bercerita Dengan Media Boneka Wayang Terhadap Kemampuan Bercakap-Cakap Anak Kelompok B Di Tk Widya Sesana Sangsit Tahun Pelajaran 2016/2017. Jurnal Pendidikan Anak Usia Dini Undiksha, 5(1).

Raharjo, S. B. (2010). Pendidikan Karakter Sebagai Upaya Menciptakan Akhlak Mulia. Jurnal Pendidikan dan Kebudayaan, 16(3), 229-238. https://doi.org/10.24832/jpnk.v16i3.456

Rahman, M. M. (2013). Metode bercerita membentuk kepribadian muslim pada anak usia dini. ThufuLa.

Setiantono, T. (2018). Penggunaan Metode Bercerita Bagi Anak Usia Dini Di Paud Smart Little Cilame Indahbandung. Empowerment, 1(2), 18-23.

Syaiful Bahri, D., \& Aswan Zain. (2010). Strategi Belajar Mengajar. Jakarta: Rineka Cipta.

Widianti, I. A. K. S., Suarni, N. K., Asril, N. M., \& Psi, S. (2015). Penerapan metode bercerita dengan media gambar untuk meningkatkan keterampilan berbicara pada anak. Jurnal Pendidikan Anak Usia Dini Undiksha, 3(1).

Yulianti, M. (2012). Peranan Metode Bercerita Dalam Mengembangkan Nilai-Nilai Moral Pada Anak Di Kelompok B2 TK Pertiwi Palu. Bungamputi, 2(3). 